\title{
MORPHOTECTONIC INTERPRETATION OF THE 23-02-2015 ALBACETE EARTHQUAKE, SPAIN
}

\author{
INTERPRETACIÓN MORFOTECTÓNICA DEL \\ TERREMOTO DEL 23-02-2015 EN ALBACETE, ESPAÑA
}

\author{
Mario Octavio Cotilla Rodríguez ${ }^{1}$ \\ Diego Córdoba Barba \\ Universidad Complutense de Madrid
}

\begin{abstract}
On 02-23-2015, an earthquake took place in the Iberian Peninsula megablock. This event is of the intraplate-type $(\mathrm{Mw}=4,7 / \mathrm{h}=17 \mathrm{~km})$ where there is a deformed morphotectonic zone. The epicenter and the normal and strike-slip solution focal mechanism were determined in the Albacete block -which has an uplifting tendency inside of the Albacete and Cuenca mesoblocks.
\end{abstract}

Keywords: Albacete, earthquake, morphotectonic, seismicity, Spain

\section{RESUMEN}

En el megabloque Península Ibérica ocurrió un terremoto (23.02.2015). El evento es del tipo de interior de placa $(\mathrm{Mw}=4,7 / \mathrm{h}=17 \mathrm{~km})$, donde existe una zona de deformación morfotectónica. El epicentro y el mecanismo focal del tipo normal y deslizamiento lateral, fueron determinados en el bloque Albacete. Este último con tendencia al levantamiento dentro de los mesobloques Albacete y Cuenca.

Palabras clave: Albacete, España, morfotectónica, sismicidad, terremoto

1 Doctor en Ciencias Física, y Profesores del Departamento de Geofísica y Meteorología, Facultad de Ciencias Físicas. Universidad Complutense de Madrid, Ciudad Universitaria, 28040 Madrid. macot@ucm.es

2 Doctor en Ciencias Física, y Profesores del Departamento de Geofísica y Meteorología, Facultad de Ciencias Físicas. Universidad Complutense de Madrid, Ciudad Universitaria, 28040 Madrid; dcordoba@ucm.es 


\section{Introduction}

By the data of the National Geographic Institute of Spain [IGN], on February 23, 2015 (16:16:31 GMT time) recorded an earthquake of 5,2 $(\mathrm{mbLg})$ and 4,7 (Mw). Another known data are: $\mathrm{h}=17 \mathrm{~km}$, coordinates 39,048 N and 02,673 W (Sotuélamos, Albacete), I= 5 (EMS98) with 198 reports (Figure 1A). The determined focal mechanism is of normal type with strike-slip movements and the main and secondary planes of $78^{\circ}$ and $303^{\circ}$, respectively. This event is the first in the zone.

The major seismic intensity is associated to 3 localities (Ossa de Montiel $(11 \mathrm{~km})$, El Bonillo $(14 \mathrm{~km})$ and Munera $(14 \mathrm{~km}))$, that surround to the epicenter for the SW, SE and E, respectively. The perceptibility of the earthquake reached for: 1) the N and NE Zaragoza $(290 \mathrm{~km})$ and Valladolid $(380 \mathrm{~km}) ; 2)$ the SE Sanlúcar de Barrameda - Cádiz (400 km) and Sevilla $(390 \mathrm{~km})$. In the relief there was not determined any rupture.

Table 1 indicates 85 aftershocks in the Castilla La Mancha Community. They are located to the $\mathrm{S}$ and in the surrounding of the main earthquake. The territory is adjacent with the Administrative Communities of: Andalucia (to SW y S), Murcia (to SE), and Valencia (to E) (Figure 2). They have been sceneries of strong earthquakes, which do not happen in Albacete (Figure 1A).

The authors presented, for the Iberian Peninsula [IP], an approach to the study of the neotectonic movements that is based on the principles of morphostructural analysis (Cotilla and Córdoba, 2004). These principles were mainly elaborated by Russian researchers as Rantsman (1979). Morphotectonic analysis has as its theoretical basis the set geostructure, morphostructure and morphosculture. It is based on the genetic principle of the development of relief, where relief is considered to be the result of the reciprocal action of internal and external processes.

Table 1. Earthquake data (2015)

\begin{tabular}{|c|c|c|c|c|}
\cline { 2 - 4 } \multicolumn{1}{c|}{} & \multicolumn{3}{c|}{ Locality } & \multicolumn{1}{c}{} \\
\hline $\mathbf{h}(\mathbf{k m})$ & Ossa de Montiel & EI Bonillo & Munera & $\boldsymbol{\Sigma}$ \\
\hline $10-15$ & 20 & 9 & 28 & 57 \\
\hline $15-20$ & 16 & 3 & 7 & 26 \\
\hline$>20$ & 2 & - & - & 2 \\
\hline $\boldsymbol{\Sigma}$ & 38 & 12 & 35 & 85 \\
\hline
\end{tabular}


Our aim is exposes briefly and the usefulness of this methodology for the recognition of the possible places of earthquake occurrence in the IP. Other authors have applied similar methods with very good results as: Zhidkov et al. (1975), Assinovskaya and Solovyev (1994), Gorshkov et al. (2000) and Cotilla and Córdoba (2013).

Figure 1. Seismicity

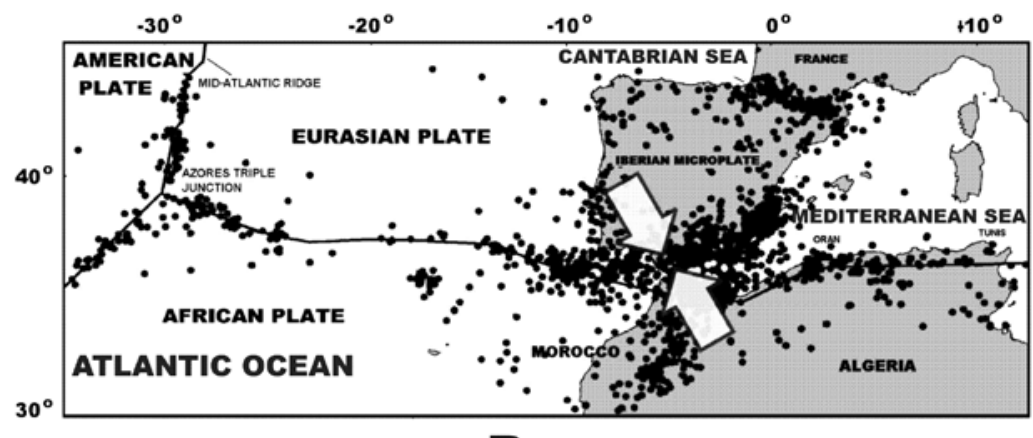

B

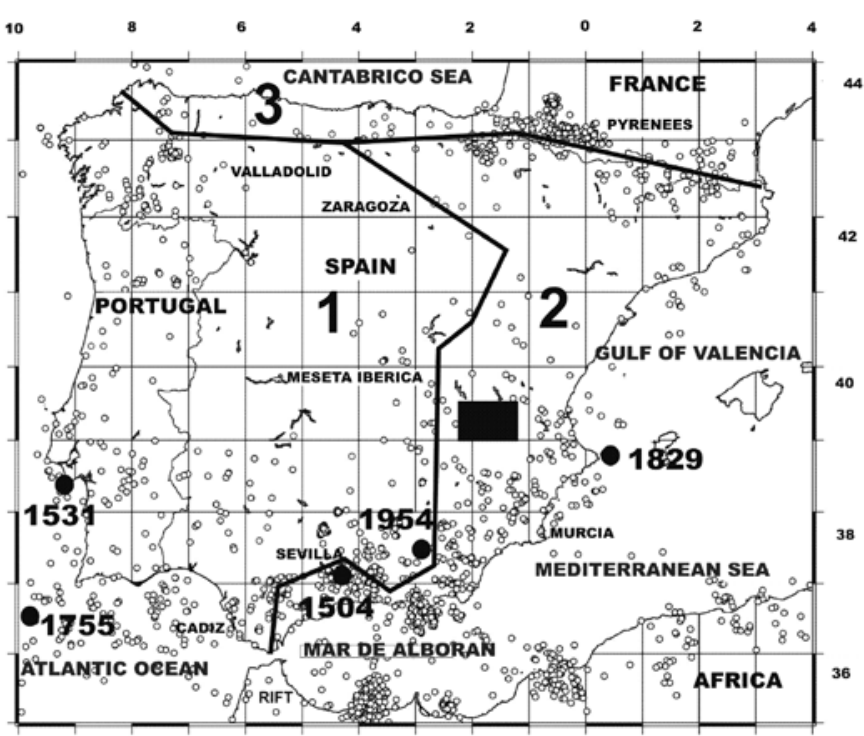

A

1A. Seismicity in Iberian megablock and surroundings.

Appear: A) black square= Albacete area; B) main fluvial basin (1) [Atlántico, 2) Mediterráneo, 3) Cantábrico]; C) irregular black line $=$ main watershed; D) white circle $=$ epicenter $(\mathrm{M}>3$ and $\mathrm{h}<$ 
Mario Octavio Cotilla Rodríguez, Diego Córdoba Barba. Interpretación morfotectónica del

terremoto del 23-02-2015 en Albacete, España

$30 \mathrm{~km})$; E) black circle $=$ epicenter of strongest earthquakes $(1504 \mathrm{Mw} \sim 6,8 ; 1531 \mathrm{Mw} \sim 8,0 ; 1755$ $\mathrm{Mw} \sim 8,5 ; 1829$ and $1954 \mathrm{Mw} \sim 6,6$ ); E) neighboring countries (France, Portugal); F) some localities.

1B. Sketch map of the Western region (Europe-Africa).

Appear: A) Main litospheric plates; B) black circle= epicenter; C) black line= main faults; D) white large arrows $=$ plate convergence tendency.

\section{Discussion and conclusions}

Recently deformed structures were located in the IP (mainly at its southern and eastern limits) (Herráiz et al., 1998). The relative motion between the European and African plates has been convergent throughout the Neogene (Figure 1B) (Dewey et al., 1989). In the Iberian microplate (or Iberian megablock), during the N-S to NNW-SSE convergence and slip between these plates, stresses from the Pyrenean and Betic borders were transmitted into the Iberian Meseta (a part of the Iberian Massif outcropping in Central Iberia) (Figure 1B). This stress field produced a set of new intraplate chains and basins. Their structural characteristics are influenced by previous crustal structures and discontinuities, and by the thickness of the sedimentary cover.

We proposed, for first time, that an extensive $(\sim 800 \mathrm{~km})$ and deformed line of tectonic weakness exists in the middle-eastern part of the Iberian megablock (Figure 3, Table 2). This line is fundamentally the A5 lineament (in white color) which possesses the greatest deformation index $(\mathrm{Ks}=0,72)$ of all the identified elements of equal category. It includes 7 second-order knots $(8,15,14,20,29,30$ and 31) and one third-order knot (28). There is a great tectonic contrast on either side of this linear structure, with 157 blocks identified to the west and 98 blocks to the east. However, there is a very strong neotectonic contrast around the A5 lineament but the seismic activity (SA) is not significant. The macroblock defined by this lineament was called Intercalado ( $\mathrm{N}^{\mathrm{o}} 4$ ) (Figure 3). It has two mesoblocks (Albacete (4.1) and Cuenca (4.2)) with different tendencies to uplift. These mesoblocks are separated by a zone of alignments (L13) of NW-SE strike, which has a significant inflexion in the surrounding of Albacete to $\sim 75^{\circ}$ strike.

Studies of major details and complexity have demonstrated the efficiency of the morphotectonic methodology for the determination of places of earthquake occurrence in 6 regions of the IP: 1) Galicia (Cotilla and Córdoba, 2003); 2) Córdoba-Granada (Cotilla et al., 2003); 3) Asturias (Cotilla et al., 2004); 4) Sistema Central (Cotilla and Córdoba, 2007); 5) 
Murcia (Cotilla and Córdoba, 2009); 7) Almería-Jaén (Cotilla and Córdoba, in press) (Figure 4). These studies recognized the activity of the Intercalado macroblock and its tendency to the movements of vertical type, inside a frame of regional compressions (Figure 3).

Figure 2. Location of epicenters in Albacete Mesoblock

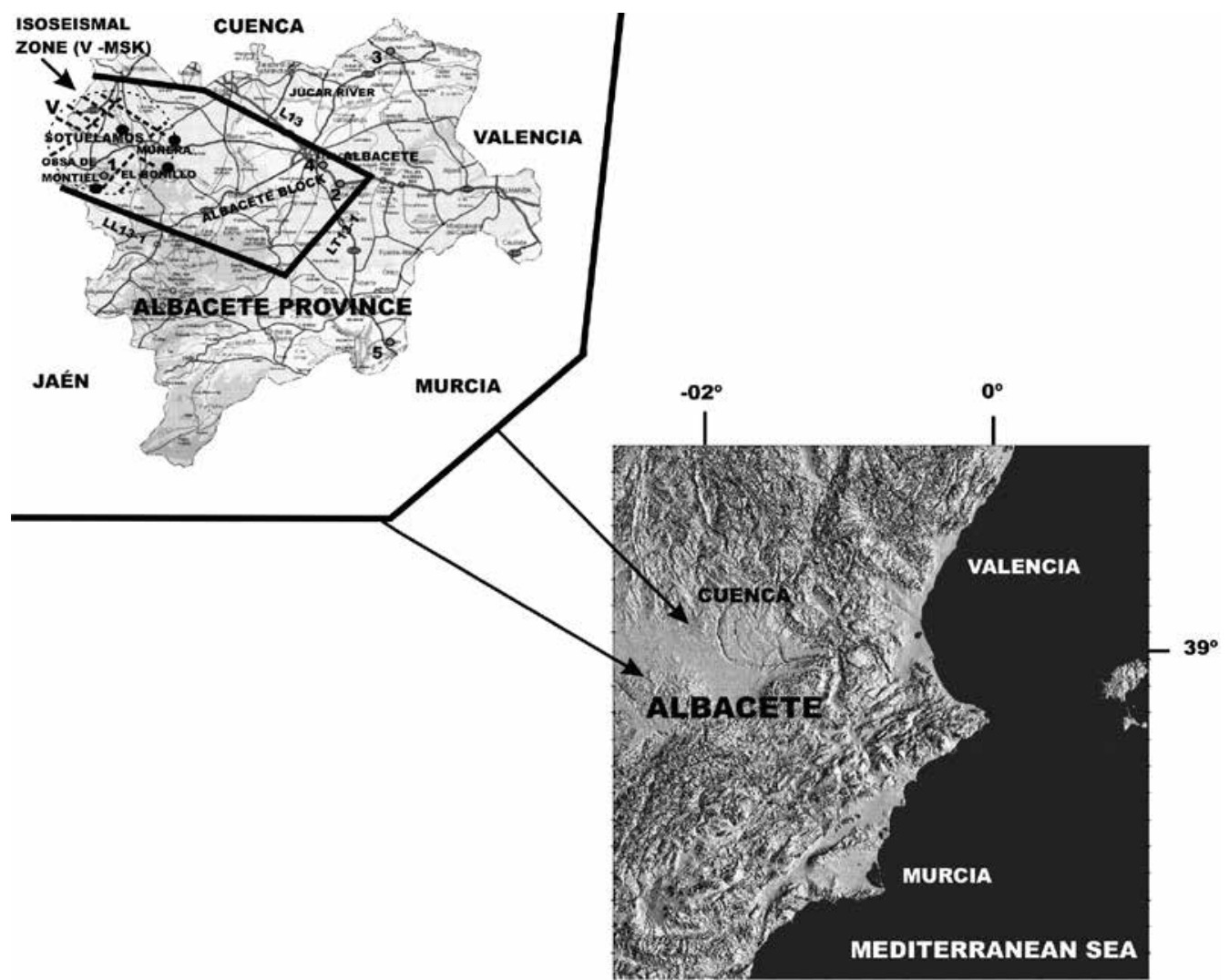

Appear: Albacete province (inside center - eastern Iberian Peninsula); A) black circle $=$ epicenter (Sotuélamos) and localities with intensities of V (EMS98) (Ossa de Montiel, El Bonillo, Munera); B) gray circles $=$ epicenters $(1=10.08 .1930(\mathrm{I}=5$ Ossa de Montiel); $2=20.03 .1933$ (I= 5 Chinchilla); $3=09.08 .1943$ ( $\mathrm{I}=5$ Casas Ibañez); $4=18.06 .1958$ ( $\mathrm{I}=6$ Hoya Gonzalo); $5=14.08 .1991$ (I=6 Caudete)); C) discontinue black lines= isoseismal zone (in the same scale); D) irregular black line= lineaments (L13, Lt13.1, LL13.1).

Albacete locates in the center-eastern of the IP megablock, concretely in the eastern fluvial basin of the first order (Mediterráneo) where exists 
a marked asymmetry defined by a clear N-S strike of the Main Divide Watershed of the first order (Figure 1A). Also in this segment the Intercaldo macroblock tilts to SE, but its mesoblocks (Albacete and Cuenca) do with certain altimetry differences. This can be deduced also from the spatial location of 85 aftershocks. From the neotectonic point of view the Albacete mesoblock is more active than that of Cuenca.

Figure 3. Simplified morphotectonic map of Iberian megablock

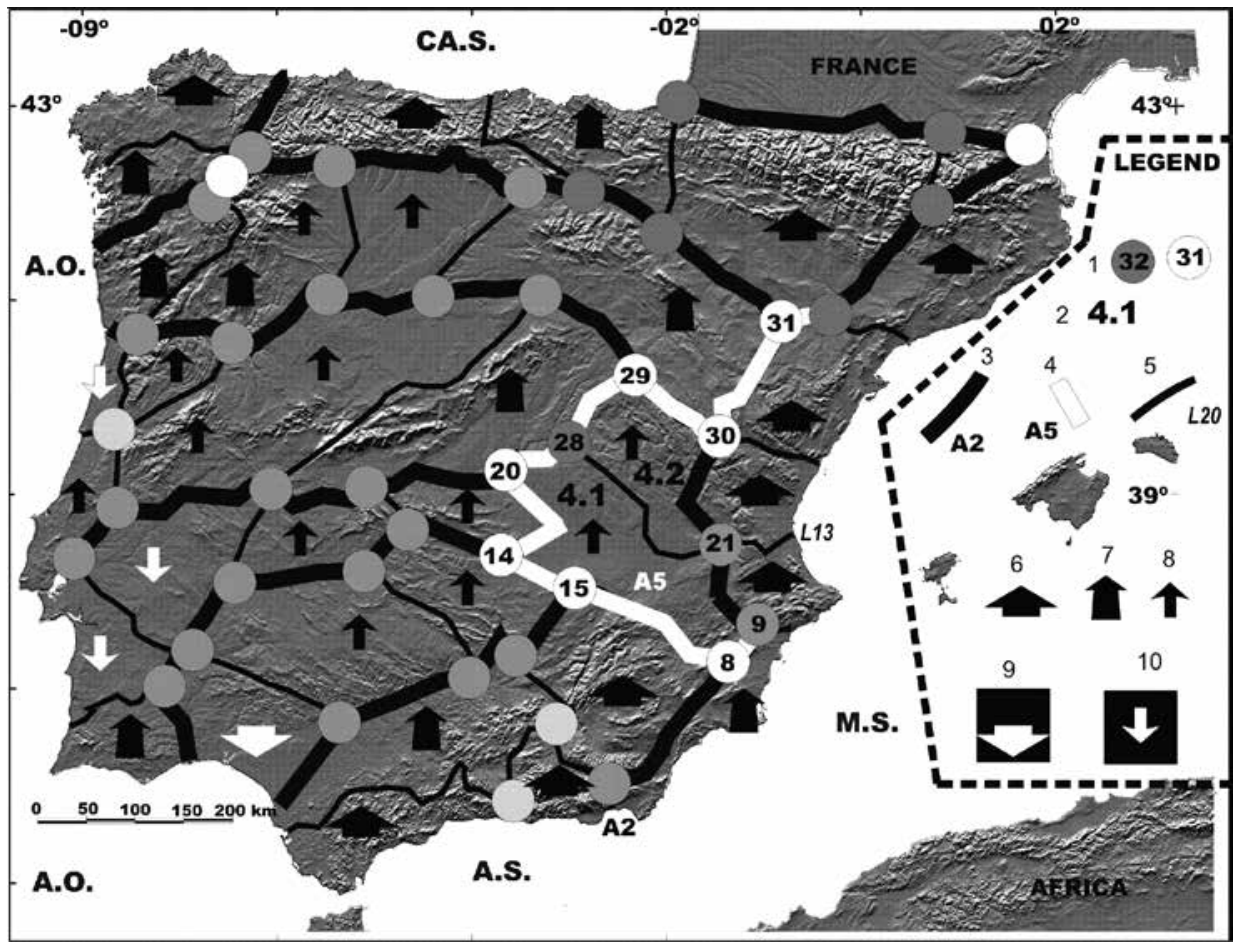

Appear: [See the legend in the figure] 1= main knots (circles with number inside); $2=$ mesoblocks $(4.1,4.2) ; 3,4,5=$ main lineaments (black and white lines); 6, 7, 8= uplifting (very active, active and weak); 9, 10= downthrows (very active and weak) [See Table 2]; A.O= Atlantic Ocean, A.S.= Alborán Sea, CA.S.= Cantabrian Sea, M.S.= Mediterranean Sea [in blue color].

The Seismic Intensity Maps show values of $\mathrm{I}=\mathrm{V}$ (MSK scale) for the Albacete and surroundings (Martín, 1984). We consider that this region is low-ranking of SA, while the maps of Epicenters Density and SA have the major values in the Albacete mesoblock (Cotilla and Córdoba, 2004). 
Table 2. Characteristics of the main knots

\begin{tabular}{|c|l|c|c|c|c|}
\hline Knot & \multicolumn{1}{|c|}{ Name } & X & Y & Rank & Lineaments \\
\hline 8 & Murcia & $-01,25$ & 38,05 & 2 & A2/A5 \\
\hline 14 & Ciudad Real & $-03,55$ & 38,50 & 2 & A3/A5 \\
\hline 15 & Montiel & $-02,50$ & 38,40 & 2 & A1/A5 \\
\hline 20 & Mocejón & $-03,50$ & 39,50 & 2 & A4/A5 \\
\hline 21 & Cofrentes & $-01,05$ & 39,10 & 3 & A2/L13 \\
\hline 28 & Embalse de Buendía & $-02,50$ & 40,30 & 3 & A5/L13 \\
\hline 29 & Moreal del Campo & $-01,25$ & 40,45 & 2 & A5/A6 \\
\hline 30 & Teruel & $-01,05$ & 40,20 & 2 & A2/A5 \\
\hline
\end{tabular}

Using the IGN data we made Tables 3 and 4 in order to understand the former SA in Albacete and Cuenca regions. In both the level of this parameter is quite similar. Also, the drawn isoseismals for 2 earthquakes of Albacete area: 1) Hoya Gonzalo (13.06.1958, I= 6); 2) Caudete $(14.08 .1991, \mathrm{I}=6)$ show irregular figures but clear strike tendencies to NE and NW, respectively (Mezcua, 1982). The first is related with the L13 alignment and the second one to A2 alignment.

This information permitted to hold that the seismicity in the $\mathrm{Al}$ bacete and surroundings is denominated as intraplate type. In addition, the 85 aftershocks (Table 1) can be considered in: A) 3 ranges of depth; being the maximum value of $22 \mathrm{~km}$; B) 2 ranges of magnitude. We assured that: A) the perceptible aftershocks were 9 (4 in Ossa de Montiel, and 5 in Munera); B) there is an evident easing of energy (events / days) in lower sense for $84 \%$ of the aftershocks for the period 23.02-04.03; C) the main event and the aftershocks are a consequence of the structural reactivation of minor order (Figure 3).

In the Albacete block (Figure 2) one can see that: A) the epicenter of the main earthquake is inside; $\mathrm{B}$ ) the majority of isoseismal with $\mathrm{V}$ value $\left(\sim 300 \mathrm{~km}^{2}\right)$ is also included; C) the predominant strike of the block is $75^{\circ}$. Also, there were represented 5 earthquakes of I> 5 in the Albacete province obtained from the catalogue of the IGN. The 65 events of the table 4 are in the Albacete mesoblock (4.1) and 3 of them (the strongest) are in the Albacete block. 
Figure 4. Morphotectonic studied areas

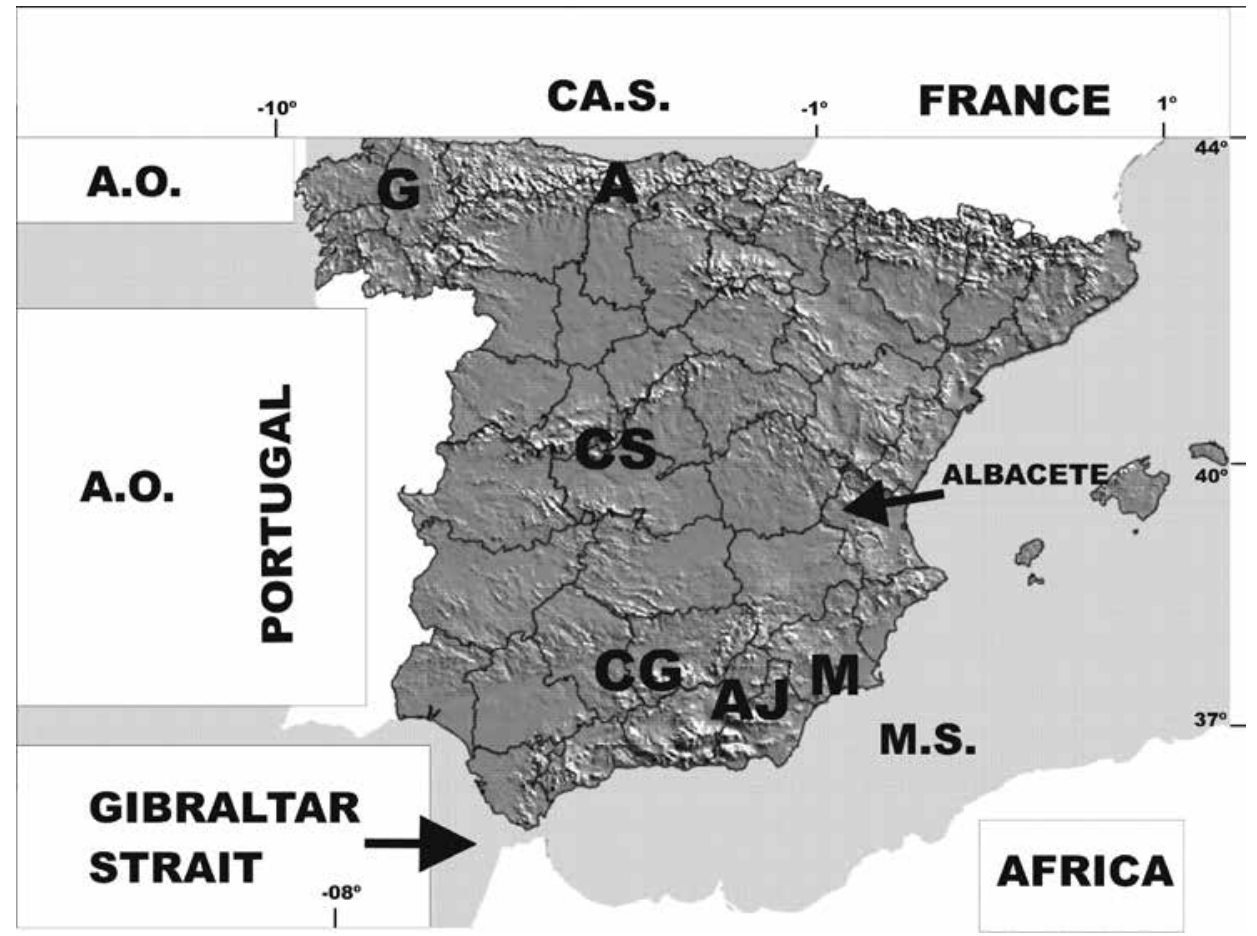

Appear: 1) Morphotectonic Regions in Spain [in gray color] ( $\mathrm{A}=$ Asturias, $\mathrm{AJ}=$ Almería-Jaén, $\mathrm{CG}=$ Córdoba-Granada, $\mathrm{CS}=$ Sistema Central, $\mathrm{G}=$ Galicia, and $\mathrm{M}=$ Murcia); 2) A.O.=Océano Atlántico; CA.S.= Cantábrico Sea, M.S.= Mediterráneo Sea [in blue color]; 3) neighboring áreas (Africa, France, Portugal) [in white color].

Table 3. Regions of our interest and their first reports

\begin{tabular}{|c|l|l|}
\hline $\mathbf{N}^{\mathbf{o}}$ & \multicolumn{1}{|c|}{ Region } & \multicolumn{1}{c|}{ Date } \\
\hline 1 & Jaén & 01.01 .1170 \\
\hline 2 & Valencia & 01.03 .1258 \\
\hline 3 & Murcia & 30.01 .1579 \\
\hline 4 & Albacete & 26.04 .1860 \\
\hline 5 & Cuenca & 17.09 .1860 \\
\hline
\end{tabular}


Table 4. Earthquake data of Albacete and Cuenca regions

\begin{tabular}{|c|c|c|c|c|c|c|}
\hline $\mathbf{N}^{\mathbf{o}}$ & Region & Reports & $\operatorname{Mmax}$ & $\operatorname{Imax}$ & Intensities / reports $(\Sigma)$ & $\begin{array}{c}\text { hmax } \\
\text { (km) }\end{array}$ \\
\hline 1 & Albacete & 65 & 4,3 & 6 & $6 / 2 ; 5 / 4 ; 4 / 5 ; 3 / 16(27)$ & 25 \\
\hline 2 & Cuenca & 63 & 3,7 & 6 & $6 / 2 ; 5 / 3 ; 4 / 4 ; 3 / 9(18)$ & 19 \\
\hline
\end{tabular}

Figure 5. Seismic zones (See Table 5)

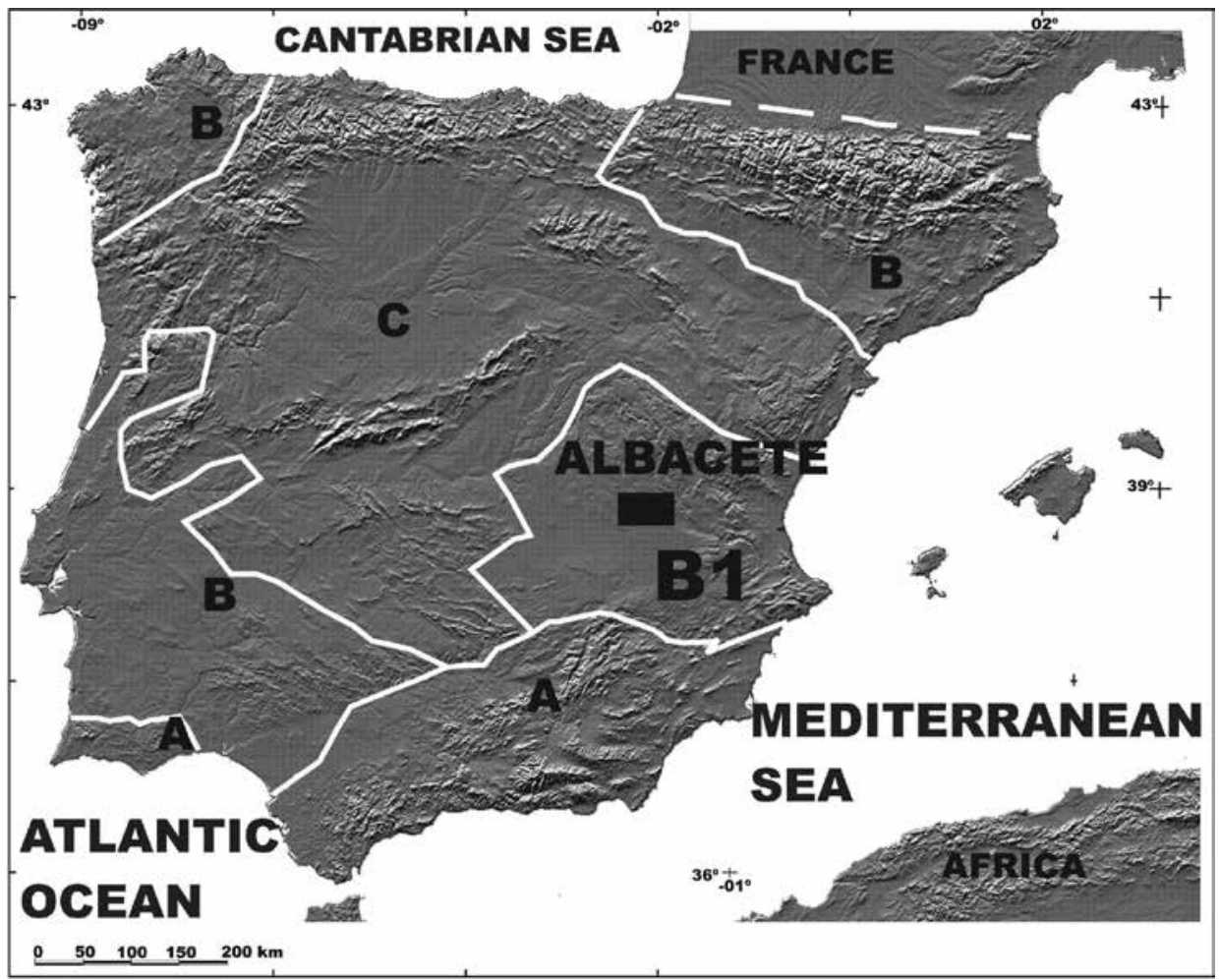

Appear: 1) Seismic zones (A, B [highest level= Zone A]); 2) irregular white line= seismic boundary; 3) Black square (Albacete) $=$ the study area 
Mario Octavio Cotilla Rodríguez, Diego Córdoba Barba. Interpretación morfotectónica del terremoto del 23-02-2015 en Albacete, España

Table 5. Characteristics of the Seismogenetic Zone

\begin{tabular}{|l|l|l|l|l|l|}
\hline \multicolumn{1}{|c|}{ Zone / Localities } & $\begin{array}{c}\text { Area } \\
\left.\mathbf{( 1 0}^{\mathbf{3}} \mathbf{k m}^{\mathbf{2}}\right)\end{array}$ & $\mathbf{M w}_{\mathbf{m a x}}$ & $\mathbf{h} \mathbf{( k m )}$ & b-value & $\begin{array}{c}\text { Focal } \\
\text { Mechanism }\end{array}$ \\
\hline $\begin{array}{l}\text { B1 / Albacete, Castellón } \\
\text { de la Plana, Ciudad Real, } \\
\text { Cuenca, Teruel, Valencia }\end{array}$ & 58,9 & $5,0-5,5$ & $10-20$ & 2,01 & $\begin{array}{l}\text { Normal / Strike } \\
\text { slip }\end{array}$ \\
\hline
\end{tabular}

Finally, we concluded that the SA model obtained by Cotilla and Córdoba (2004) have a good adjustment and correspondence with: A) the main earthquake of this series (location, magnitude, intensity and focal mechanism); B) the epicenter locations and depths of aftershocks (Figure 5, Table 5). Therefore, the Albacete block and the mesoblock of same name are active structures, and consistently the Intercalado macroblock is also active, as forecasted Cotilla and Córdoba (2004).

\section{Acknowledgements}

Amador García Sarduy prepared all figures. The budgets mainly came from two projects: TSUJAL (CGL2011-29474-C02-01) and GR35/10-A/910549. Grateful to the anonymous reviewer.

\section{References}

Assinovskaya, B.A. and Solovyev, S.L. (1994). Definition and description of the sources zone of potential earthquakes in the Barents Sea. Physics of the Solid Earth, 29(8), 664-675.

Cotilla, M.O. and Córdoba, D. (2013). El terremoto de Lorca-Murcia, España (2011): Interpretación morfotectónica. Revista Geográfica, $154,115-131$.

Cotilla, M.O. and Córdoba, D. (2009). Morfotectónica de Murcia, España. Revista Geográfica, 146, 77-110.

Cotilla, M.O. and Córdoba, D. (2007). A morphotectonic study of the Central System, Iberian Peninsula. Russian Geology and Geophysics, 48(4), 378-387.

Cotilla, M.O. and Córdoba, D. (2004). Morphotectonics of the Iberian Peninsula. Pure appl.geophys, 42(4), 589-602.

Cotilla, M.O., Córdoba, D. and Herráiz, M. (2004). Main morphotectonic characteristics of Asturias, Spain. Geofisica International, 44(1), 65-101. 
Cotilla, M.O. and Córdoba, D. (2003). Caracterización morfotectónica de Galicia, España. Revista Geofisica, 58, 5-56.

Cotilla, M.O. and Córdoba, D., (en prensa). Delimitación de unidades morfotectónicas en el sector Almería-Jaén, España. Revista Geológica Colombiana,38, 1-15.

Cotilla, M.O., Córdoba D. and Sánchez F. (2003). Morphotectonic study of two regions in the Centre-South segment of Spain: Córdoba and Granada. Geotectonics, 47(3), 215-240.

Dewey, J.F., Helman, M.L., Urco, E., Hutton, D. and Knott, S.D. (1989). Kinematics of the Western Mediterranean. In Alpine Tectonics (Eds. Coward D., Dietrich D. and Park R.G.), Special Publication of the Geological Society of London 45, 265-283.

Gorshkov, A.I., Kuznetsov, I.V., Panza, G.F. and Soloviev, A.A. (2000). Identification of future earthquake sources in the Carpatho-Balkan orogenic belt using morphostructural criteria. Pure appl.geophys., 157, 79-95.

Herráiz M., De Vicente, G., Lindo, R., Giner, J., Simón, J.L., Gómez-Casado J.M., Vadillo O., Rodríguez-Pascuas M., Cicuendez J.I., Casas A., Cabañas L., Rincón, P., Cortés M., Ramírez M. and Lucini M. (2000). The recent (Upper Miocene to Quaternary) and present tectonic stress distribution in the Iberian Peninsula. Tectonics, 19(4), $762-786$.

Martín A.J. (1984). Riesgo sísmico en la Península Ibérica. PhD thesis, Instituto Geográfico Nacional, II Parts, Madrid.

Mezcua J. (1982). Catálogo de isosistas de la Península Ibérica. Publicación Técnica, 202, 62 pp. Instituto Geográfico Nacional, Madrid.

Rantsman E.Ya. (1979). Sites of earthquakes and morphostructures of mountain countries. , Moscú: Editorial Nauka, p.171.

Zhidkov, M. P., Rotvain, I.M. and Sadowskiy, A.M. (1975). Pronóstico sobre las áreas más probables de ocurrencia de los terremotos más fuertes, IV. Papers of Seismology, 8, 53-70. 